\title{
ASSESSING THE EFFECTS OF PHYSICAL ACTIVITY ON CHILDREN AND ADOLESCENTS HODGKIN'S LYMPHOMA SURVIVORS: A SYSTEMATIC REVIEW
}

\author{
Dario Colella, \\ Domenico Monacisi \\ Department of Humanities, \\ Cultural Heritage, Education Sciences, \\ University of Foggia, \\ Foggia, Italy
}

\begin{abstract}
:
Physical activity can improve metabolism, lung functionality, aerobic capacity, physical fitness components and quality of life among children and adults diagnosed with cancer. The daily practice of physical activity and physical fitness levels are important factors to cancer care and prevention, showing positive effects on the immune system and hematologic malignancies. Hodgkin's lymphoma is a cancer of the lymphatic system, originated from B lymphocytes (a type of white blood cell) present in the lymph nodes, spleen, bone marrow, blood and numerous other organs. This system has a defense function, protecting organism from external agents and diseases. The aim of this systematic review is to analyze the effects of physical activity on fatigue, physical fitness levels and quality of life in children and adolescents Hodgkin's lymphoma survivors. The PRISMA protocol was used to conduct a systematic review of SportDiscuss, PubMed, Scopus, Web of Science and Pedro databases. 4 articles met inclusion criteria (randomized controlled trials, pre-post intervention studies with and without control group, pilot studies or preliminary studies; full-text and peer-reviewed studies; diagnosis of lymphoma during childhood or adolescence; studies using validated assessment tools or a combination of validated and non-validated tools; studies including physical activity, physical fitness and quality of life as outcomes; studies focusing Hodgkin Lymphoma exclusively; studies published in English). Results evidence a progressive decline in physical activity levels, a progressive decrease in $\mathrm{VO}_{2} \max$, increased fatigue, muscular strength reduction, and major risk of cardiovascular diseases in Hodgkin's Lymphoma survivors. Future research should clarify the effects of physical activity on HL management and etiology, to reach definitive conclusions and develop specific policy recommendations.
\end{abstract}

i Correspondence: email domenico.monacis@unifg.it, domenicomonacis@hotmail.it 
Keywords: physical activity; Hodgkin's lymphoma; children; motor development; immune system

\section{Introduction}

The decline in levels of physical activity in children and adolescents is a health-global priority (Abarca-Gómez et al., 2017), having a significant effect on chronic-degenerative disease development in middle-adult age (Zhang et al., 2019; Yu et al., 2018; Bhaskaran et al., 2018). The health-related benefits of physical activity and physical fitness levels include BMI management, (Al-Khudairy et al., 2017), cardiovascular system improvement (Abrignani et al., 2019) muscle and skeletal strengthening (Alves et al., 2019), but also mental health and well-being (Hosker et al., 2019), reducing depression and anxiety (Pascoe et al., 2019) and improving cognitive and academic performances (Singh et al., 2019).

Recent findings suggest a changing in patterns of cancer development, identifying associations between diet and physical activity with one or more cancers (Wiseman, 2018; World Cancer Research Found, 2018). Physical activity can improve health, metabolism, aerobic capacity, and quality of life among children and adults diagnosed with cancer (Brunet et al., 2018; Van Dijk-Lokkart et al., 2019; Kowaluk et al., 2019).

The daily practice of physical activity and physical fitness levels are important factors to cancer care and prevention, showing positive effects on the immune system and hematologic malignancies (Sitlinger et al., 2020; Matthews et al., 2020; Munsie et al., 2019).

According to the National Cancer Institute lymphoma is a term used to identify cancer involving B-cells of the lymphatic system (NIC), differing in two main types: Hodgkin lymphoma (HL) and non-Hodgkin lymphoma (NHL).

Hodgkin's lymphoma (HL) is defined by the National Cancer Institute ( NIC) as one of "the few pediatric malignancies that shares aspects of its biology and natural history with an adult cancer", and it is one of the most curable cancer in childhood and adult age (approximately 90\% to 95\%). Hodgkin lymphoma involves 6\% of total childhood cancers (NCI). The incidence of HL is age-related, with a higher prevalence in children and young aged 14 years, and immune system maturation and development dependent, increasing in individuals with immunodeficiency (Crombie et al., 2019).

A recent review shows the following results (a) exercise can invigorate B cells; (b) acute exercise can mobilize immature B-cells to the greatest extent; (c) an increase the number of total B-cells after exercise; (d) invigorate B-cells after exercise; (e) exercise benefits on vaccines response, related to improved B-cells functions; (f) an increase frequencies of B-regulatory cells mediating the immune responses (Sitlinger et al., 2020). In particular, aerobic exercise and cardiorespiratory physical fitness training can be efficacy to promote changes in the immune system, influencing the response of leukocytes, lymphocytes, lymphocyte subpopulations, interleukins, NK cells and immunoglobulins (Gonçalves et al., 2020). Findings reveals that B-cells activation is an 
important factor contributing to B-cell Lymphoma development, mediating the role of the immune system for BMI and physical activity (Saberi Hosnijeh et al., 2020).

The aim of this systematic review is to analyze the effects of physical activity on fatigue, physical fitness levels and quality of life in children and adolescents Hodgkin's lymphoma survivors.

\section{Methods}

Using the PRISMA model, "Preferred Reporting Items for Systematic reviews and MetaAnalyzes" (Moher, Liberati, Tetzlaff, \& Altman, 2009) a systematic literature review was performed to analyze the relationship between physical activity and physical fitness related quality of life in children and adolescents Hodgkin's lymphoma survivors.

The literature search was performed by consulting six electronic databases (SPORTDiscuss, PubMed, Scopus, Web of Science, Google Scholar and Pedro), associating the terms "Physical Activity" AND "Hodgkin Lymphoma".

The last bibliographic search dates back to 12/10/2020. The articles identified from the literature search were selected only if they were related to Hodgkin's lymphoma.

To make the bibliographic search more complete and not to exclude some works, the following gray literature was consulted:

- Exercise sciences;

- Sports Science: International Scientific Journal of Kinesiology;

- Research desk;

- Kinesiology: International Journal of Fundamental and Applied Kinesiology;

- Journal of physical education and sport

- Montenegrin journal of sports science and medicine;

- Analele Universității din Oradea. Facicula Educaţie Fizică şi Sport.

Only articles already published, peer-reviewed and in full-text were considered. After removing the duplicates, the lead author selected the relevant articles based on the title and abstract analysis. The authors jointly contributed to resolving uncertainties about the relevance or otherwise of some studies. Subsequently, the full-text texts were analyzed to identify those capable of satisfying the inclusion criteria. All studies that met the inclusion criteria were then analyzed separately and independently by the author 1 and 2. Any disagreements on the selection of works were resolved through a critical discussion between the authors. The synthesis and analysis of the data of the studies included in the systematic review was carried out by the author 2. Data relating to (I) author / year of publication; (II) age diagnosed lymphoma; (III) age at assessment; (IV) received medical treatment and disease stage; (V) smoking habit; (VI) levels of physical activity; aim and scope; (iii) sample, (iii) study design; (iv) assessment tools; (v) significant results were reported. 


\subsection{Inclusion Criteria}

Articles meeting the following inclusion criteria were included in the systematic review: (a) randomized controlled trials (RCTs), pre-post intervention studies with and without control group, pilot studies or preliminary studies; (b) full-text and peer-reviewed studies; (c) diagnosis of lymphoma during childhood or adolescence; (d) studies using validated assessment tools or a combination of validated and non-validated tools; (e) studies including physical activity, physical fitness and quality of life as outcomes; (f) studies focusing Hodgkin Lymphoma exclusively; (g) studies published in English. Literature reviews, lectures, mastery thesis, monographs, conference papers, dissertations and similar documents were excluded.

\subsection{Risk of Bias}

The following criteria were used to assess the quality and risk of error of the studies considered: (a) explanation of the sample recruitment process; (b) validity of the assessment tools; (c) drop-out of less than $30 \%$ of the total pre / post intervention sample; (d) analysis of variance and co-variance; (e) description of the results obtained and reported effect-size; (f) precision of the effects obtained (eg. confidence interval). Each item was assigned a score of 2 if the study provided clear and precise information; 0 if the requested information was not reported; 1 the information was not entirely accurate.

The works were then tagged as "high" or "low" quality studies. The present review only considered studies identified as "high quality" which satisfy at least 3 out of 6 items (equal to or greater than $50 \%$ ).

\section{Results}

The initial database research produced 518 results; 5 additional works have been added deriving from other sources. After removing the duplicates (85), 438 articles were analyzed based on title and abstract, and 30 articles were analyzed in full text for eligibility (Figure 1).

26 studies didn't meet the inclusion criteria: 7 didn't provide physical activity assessment or intervention (27\%), 8 age of the sample or not specified age at diagnosis (31\%), 6 non-specific focus on Hodgkin's lymphoma (23\%), 5 conference paper, thesis and abstract (19\%).

Four studies were selected, analyzed and included in the review process, evaluating physical activity and physical fitness levels in HLS (Hodgkin's Lymphoma survivors). Two studies are cross-sectional, describing fitness and quality of life in HLS focusing on cardiovascular status and risk of cardiovascular diseases, with and without GC (Wogksch et al., 2019; Adams et al., 2004), and the others two studies are longitudinal, involving the evolution of physical fitness parameters, fatigue and cardiovascular disease over time (Macpherson et al., 2015; Jones et al., 2014).

All studies were conducted after medical treatment of lymphoma (chemotherapy and radiation therapy). Age at diagnosis range from 13.8 (Wogksch et al., 2019) to 28.7 
(Jones et al., 2004), while age at assessment range from 10 (Wogksch et al., 2019) to 27.5 years after diagnosis (Adams et al., 2004); only the study of Macpherson et al. (2014) was conducted immediately after medical treatment. Sample mainly consists of stage II disease in two studies (Macpherson et al., 2015; Adams et al., 2004); Jones et al. (2014) considers the severity of CV events for sample recruitment, and Wogksch et al. (2015) doesn't specify the stage of disease.

The proportion of current, past and non-smoker are similar in all of 3 studies reporting related data (Wogksch et al., 2019; Jones et al., 2014; Adams et al., 2004), with a large percentage of non-smoker or past smoker (about 80\%). Physical activity surveillance reveals that most of HLS are insufficiently physically active, not respecting international recommendations and guidelines (Wogksch et al., 2019; Macpherson et al., 2015; Jones et al., 2014).

Assessment involves a mixed assessment, integrating and combining motor test (Sit and reach test, 6-min walk test, exercise stress test), objective methods (ECG, echocardiogram, ECG Holter monitor, muscular strength etc.) with subjective methods (self- report) for the evaluation of physical activity levels and quality of life.

Studies reveal a progressive decline in endurance, a decrease in $\mathrm{VO}_{2}$ max, increased fatigue, and muscular strength reduction in HLS; risk cardiovascular disease are inversely related to levels of physical activity, with the $51 \%$ of reduction for PA $\geq 9$ MET hours/week ${ }^{-1}$. According to smoking habit no significant results were found. Table 1 shows a more detailed analysis of the studies reviewed. 
Dario Colella, Domenico Monacis

ASSESSING THE EFFECTS OF PHYSICAL ACTIVITY ON CHILDREN AND

ADOLESCENTS HODGKIN'S LYMPHOMA SURVIVORS: A SYSTEMATIC REVIEW

Table 1: Physical Activity, Fitness Levels and Quality of Life in Childhood and Adolescents HL Survivors

\begin{tabular}{|c|c|c|c|c|c|c|c|c|c|c|}
\hline $\begin{array}{l}\text { Authors, } \\
\text { Years }\end{array}$ & Sample & $\begin{array}{c}\text { Age at } \\
\text { Diagnosis }\end{array}$ & $\begin{array}{c}\text { Age at } \\
\text { Assessment }\end{array}$ & $\begin{array}{c}\text { Medical } \\
\text { Therapy and } \\
\text { Disease Stage }\end{array}$ & $\begin{array}{c}\text { Smoking } \\
\text { Habit }\end{array}$ & $\begin{array}{l}\text { Levels } \\
\text { of PA }\end{array}$ & $\begin{array}{c}\text { Aim and } \\
\text { Scope }\end{array}$ & $\begin{array}{l}\text { Study } \\
\text { Design }\end{array}$ & $\begin{array}{l}\text { Assessment } \\
\text { Tools }\end{array}$ & Results \\
\hline $\begin{array}{l}\text { Wogksch et } \\
\text { al., } 2019\end{array}$ & $\begin{array}{l}\text { ES=336 } \\
\text { HLS; } \\
\text { CG= } 327 \\
\text { NHL; } \\
\text { Median } \\
\text { age= } \\
36.7, \\
\text { range } \\
19.1 \text { to } \\
60.6 \text { years } \\
\text { old }\end{array}$ & $\begin{array}{l}\text { Mean age: } \\
13.8 \text { years }\end{array}$ & $\begin{array}{l}\text { At least } 10 \\
\text { years from } \\
\text { original } \\
\text { diagnosis }\end{array}$ & $\begin{array}{l}\text { Chemotherapy } \\
\text { and radiation } \\
\text { therapy; } \\
\text { Stage disease no } \\
\text { specified }\end{array}$ & $\begin{array}{l}\mathrm{EG}= \\
22.0 \% \\
\text { (current), } \\
19.0 \% \\
\text { (past) and } \\
59.0 \% \\
\text { (never) }\end{array}$ & $\begin{array}{l}\mathrm{EG}=53.6 \% \\
\text { (physically } \\
\text { active) } \\
\mathrm{CG}=\text { N/A }\end{array}$ & $\begin{array}{l}\text { Describing } \\
\text { fitness and } \\
\text { associated } \\
\text { health-related } \\
\text { quality of life in } \\
\text { survivors of } \\
\text { childhood } \\
\text { Hodgkin } \\
\text { lymphoma } \\
\text { (HL) compared } \\
\text { with a control } \\
\text { population } \\
\text { without } \\
\text { childhood } \\
\text { cancer }\end{array}$ & $\begin{array}{l}\text { Cross } \\
\text { Sectional } \\
\text { Study }\end{array}$ & $\begin{array}{l}\text { Anthropometrics, } \\
\text { muscular strength } \\
\text { (Biodex Medical } \\
\text { Systems, Shirley, } \\
\text { NY), muscular } \\
\text { endurance (knee } \\
\text { work fatigue), } \\
\text { flexibility (Sit and } \\
\text { reach test), and } \\
\text { cardiopulmonary } \\
\text { endurance (6-min } \\
\text { walk test), } \\
\text { Peripheral nervous } \\
\text { system integrity } \\
\text { (Total Neuropathy } \\
\text { Score; Wampler et } \\
\text { al., 2006) and } \\
\text { balance (Ford- } \\
\text { Smith et al., 1995), } \\
\text { and quality of life } \\
\text { (Medical } \\
\text { Outcomes Survey } \\
\text { 36-Item Short } \\
\text { Form; Reulen et } \\
\text { al., 2006) }\end{array}$ & $\begin{array}{l}\downarrow \text { endurance and } \\
\text { neuropathy in male } \\
\text { survivors }(P<0.01) ; \\
\downarrow \text { endurance }(P<0.01), \\
\text { quadriceps strength }(P< \\
0.01) \text {, and neuropathy }(P \\
<0.01) \text { in female } \\
\text { survivors; } \\
\text { - Quadriceps strength ( } P \\
<0.01) \text {, endurance }(P< \\
0.01) \text {, and neuropathy }(P \\
<0.01) \text { associated with } \\
\text { lower physical } \\
\text { component on the Health } \\
\text { Related Quality of Life. }\end{array}$ \\
\hline $\begin{array}{l}\text { Macpherson } \\
\text { et al., } 2015\end{array}$ & $\begin{array}{l}\mathrm{M}=44, \\
\mathrm{~F}=59, \\
\text { mean } \\
\text { age }= \\
15.46 \mathrm{yrs} \\
\text { (range 13- } \\
21 \text { years) }\end{array}$ & $\begin{array}{l}15.46 \\
\text { years, } \\
\text { range } 13 \text { to } \\
21 \text { years } \\
\text { old }\end{array}$ & $\begin{array}{l}\text { 12- and 36- } \\
\text { months post- } \\
\text { therapy }\end{array}$ & $\begin{array}{l}\text { Chemotherapy } \\
\text { and radiation } \\
\text { therapy; } \\
\text { Stage II disease } \\
(65 \%)\end{array}$ & N/A & $\begin{array}{l}\text { End of } \\
\text { therapy= } \\
2.74 \pm 2.17 \\
\text { DWE; } \\
12 \text { months } \\
\text { post- } \\
\text { therapy= } \\
2.70 \pm 1.99 \\
36 \text { months } \\
\text { post } \\
\text { therapy= } \\
2.92 \pm 2.16\end{array}$ & $\begin{array}{l}\text { Exploring the } \\
\text { trajectories of } \\
\text { and relationship } \\
\text { between } \\
\text { amount of } \\
\text { exercise and } \\
\text { fatigue }\end{array}$ & $\begin{array}{l}\text { Longitudinal } \\
\text { Study }\end{array}$ & $\begin{array}{l}\text { Child Cancer } \\
\text { Survivors } \\
\text { Surveillance } \\
\text { questionnaire } \\
\text { (Robison et al., } \\
\text { 2005) }\end{array}$ & $\begin{array}{l}\uparrow \text { Exercise and fatigue } \\
\text { over time; } \\
\uparrow \text { amount of exercise at } \\
\text { end of therapy, at } 12(\mathrm{p}= \\
0.02) \text { and } 36(\mathrm{p}= \\
0.0008) \text { months post- } \\
\text { therapy }\end{array}$ \\
\hline
\end{tabular}


Dario Colella, Domenico Monacis

ASSESSING THE EFFECTS OF PHYSICAL ACTIVITY ON CHILDREN AND

ADOLESCENTS HODGKIN'S LYMPHOMA SURVIVORS: A SYSTEMATIC REVIEW

\begin{tabular}{|c|c|c|c|c|c|c|c|c|c|c|}
\hline $\begin{array}{l}\text { Jones et al., } \\
2014\end{array}$ & $\begin{array}{l}\mathrm{N}=1187, \\
\text { survivors } \\
\text { of } \mathrm{HL} ; \\
\text { median } \\
\text { age: } 31.2 \\
\text { years; } \\
\text { range, } \\
18.0 \text { to } \\
48.9 \text { years } \\
\text { at study } \\
\text { entry }\end{array}$ & $\begin{array}{l}16.7 \text { years, } \\
\text { range } 8.2 \\
\text { to } 28.7 \\
\text { years old }\end{array}$ & $\begin{array}{l}41.9 \text { years, } \\
\text { range } 21.9 \text { to } \\
57.9\end{array}$ & $\begin{array}{l}\text { Chemotherapy } \\
\text { and radiation } \\
\text { therapy; }\end{array}$ & $\begin{array}{l}15.1 \% \\
\text { (current), } \\
27.4 \% \\
\text { (past) and } \\
57.5 \% \\
\text { (never) }\end{array}$ & $\begin{array}{l}35.9 \%=0 \\
\text { MET x } \\
\text { hours/week }\end{array}$ & $\begin{array}{l}\text { Investigating } \\
\text { the association } \\
\text { between } \\
\text { exercise and } \\
\text { risk of } \\
\text { cardiovascular } \\
\text { events in adult } \\
\text { survivors of HL } \\
\text { participating in } \\
\text { the Childhood } \\
\text { Cancer } \\
\text { Survivor Study }\end{array}$ & $\begin{array}{l}\text { Longitudinal } \\
\text { Study }\end{array}$ & $\begin{array}{l}\text { Youth Risk } \\
\text { Behavior } \\
\text { Surveillance } \\
\text { Survey, single item } \\
\text { (Troped et al., } \\
\text { 2007) }\end{array}$ & $\begin{array}{l}\downarrow \text { incidence of any CV } \\
\text { event across increasing } \\
\text { MET categories (Ptrend } \\
=.002 \text { ); } \\
\uparrow \text { physical activity (i.e., } \\
\geq 9 \text { MET hours/week }{ }^{-1} \text { ) } \\
\text { was associated with the } \\
51 \% \text { reduction in the risk } \\
\text { of any CV event in } \\
\text { comparison with not } \\
\text { meeting the guidelines (p } \\
=.002 \text { ) }\end{array}$ \\
\hline $\begin{array}{l}\text { Adams et al., } \\
2004\end{array}$ & $\begin{array}{l}\mathrm{N}=48 \\
\mathrm{M}=23 \\
\mathrm{~F}=25\end{array}$ & $\begin{array}{l}16.5 \text { years, } \\
\text { range } 6.3 \\
\text { to } 25.0 \\
\text { years old }\end{array}$ & $\begin{array}{l}14.3 \text { years, } \\
\text { Range to } 5.0 \\
\text { to } 27.5\end{array}$ & $\begin{array}{l}\text { Stage II disease } \\
(64.6 \%)\end{array}$ & $\begin{array}{l}27.0 \% \\
\text { (current), } \\
14.5 \% \text { (in } \\
\text { the last } 4 \\
\text { weeks) } \\
\text { and } \\
58.5 \% \\
\text { (never) }\end{array}$ & N/A & $\begin{array}{l}\text { Assessing } \\
\text { cardiovascular } \\
\text { status } \\
\text { Hodgkin's } \\
\text { Lymphoma } \\
\text { survivors and } \\
\text { the increased } \\
\text { risk for } \\
\text { cardiovascular } \\
\text { diseases }\end{array}$ & $\begin{array}{l}\text { Cross } \\
\text { Sectional } \\
\text { Study }\end{array}$ & $\begin{array}{l}\text { Echocardiogram, } \\
\text { ECG, exercise } \\
\text { stress test, 24-hour } \\
\text { ECG (Holter } \\
\text { monitor), Short- } \\
\text { Form } 36 \text { quality- } \\
\text { of-life instrument } \\
\text { (Ware \& } \\
\text { Sherbourne, 1992) }\end{array}$ & $\begin{array}{l}\downarrow \mathrm{VO} 2 \mathrm{max} \text { during } \\
\text { exercise }(<20 \mathrm{~mL} / \mathrm{kg} / \mathrm{m} 2) \\
\text { in } 30 \% \text { of survivors; } \\
\text { VO2max correlated with } \\
\text { increasing fatigue, } \\
\text { increasing shortness of } \\
\text { breath (both, } r=-0.35 ; \\
P=.02) \text {, and decreasing } \\
\text { physical component } \\
\text { score on the SF-36 }(r= \\
0.554 ; P=.00017) .\end{array}$ \\
\hline
\end{tabular}

Note: HLS= Hodgkin's Lymphoma Survivors; NHLS= No Hodgkin's Lymphoma; DWE= days of exercise for week; MET= metabolic equivalent on task; PA= physical activity; $\downarrow=$ decrease; $\uparrow=$ increase 


\section{Discussion}

The aim of the current research was to present an updated review of the literature on levels of physical activity, physical fitness and quality of life in young Hodgkin's Lymphoma survivors. Results highlights that an increase in fatigue, a decrease in $\mathrm{VO}_{2}$ max, muscles strength and endurance levels, and lower physical component associated with quality of life.

A recent review underlines that (a) higher level of physical activity seems to be inversely associated with lymphoma development (compared to the lower PA level); (b) female subjects appear to better benefit from higher PA levels than boys (Davies et al., 2020). At the same time, a large percentage of adolescents and young adult cancer survivors (AYACs) do not meet the lifestyle guidelines and recommendations for PA, BMI, and/or smoking, involving several late effects and/or comorbidities (Bøhn et al., 2020).

Moreover, young Hodgkin's Lymphoma survivors' evidence high levels of persistent physical fatigue, emotional distress, and cognitive decline, with a progressive reduction in the quality of life (Mounier et al., 2019; Trachtenberg et al., 2019). Despite the well-known relationship between aerobic capacity and lung function, the improvements in lung function are correlated with highest physical fitness levels during childhood and adolescence through early adulthood, and being active during evolutive age is associated with improved lung function in adulthood (Puente-Maestu \& Stringer, 2018).

The study of Deisenroth et al. (2016) underlines a significant decrease in strength levels (especially in lower extremities) and quality of life in children with cancer, already during the primary medical treatments. The study of Garcia-Hermoso et al. (2020) reveals that cardiorespiratory fitness is inversely correlated with total white blood cells (WBC), such as neutrophils, lymphocytes, monocytes, basophils, and eosinophils, and MVPA in boys. Furthermore, highest levels of cardiorespiratory fitness are associated with a normal range of $\mathrm{WBC}$, strengthening the immune system of children and adolescents (Garcia-Hermoso et al., 2020).

The study of Hooke et al. (2019) evaluates the effects of PA and fatigue in children and adolescents with cancer (acute lymphoblastic leukemia, lymphoma, and solid tumors). Results show s progressive decline in trends of fatigue during treatments of ALL (acute lymphoblastic leukemia) and lymphoma, and an increase in children with solid tumors, even if PA levels were unchanged in all sample. Recent findings suggest that childhood BMI is positively correlated with hematologic malignancies, and highest childhood BMI is a determinant of Non-Hodgkin lymphoma and diffuse large B-cell lymphoma (Celind et al., 2020).

Kowaluk et al. (2019) assesses PA and quality of life in a sample of children undergoing cancer treatment, during and after treatment completion, finding the following results: (a) during treatment children didn't following MVPA physical activity guidelines and recommendations (at least 60min per day at week); (b) after treatment 
children spent at least 30 minutes per week in MVPA, while healthy children were physically active at least 5 days per week; (c) quality of life of children with cancer is significantly lower and different from the quality of life of healthy children.

A research investigating pattern of physical activity in childhood with cancer shows that PA barriers persist both during and after therapy, with children preferring short-term activity (10-20 minutes), low-intensity activity (i.e. walking), and carried out in the afternoon (Ross et al., 2018).

\section{Conclusion}

The present review underlines a progressive decline in endurance and muscular strength, increasing fatigue and negatively influencing quality of life in childhood and adolescents HL survivors. The data are quite worrying and sedentary lifestyles, associated with a reduction in the quality of life, could have negative consequences on the general state of health, impacting even more the health system in the medium-long term. Daily practice of physical activity, as well as active lifestyles, could have an important role and positive effects both on prevention of HL during childhood and adolescence, and enhance physical fitness status after medical treatment (chemotherapy and radiotherapy). Movement specialist, expert in motor sciences and health-care professionals should encourage adults to be physically active and promote active lifestyles to maintain and obtain better health status. Low-intensity aerobic activity (i.e. group of walking) and lowimpact muscle strengthening activity involving total body movement (i.e. yoga, tai-chi etc.) could be useful to promote physical fitness components, especially during the first period after cancer treatment. Special attention should be given to youngest, as the BMI management, the acquisition of active lifestyles, the development of motor components and a positive attitude towards physical activity, with all positive consequences on immune system, can be best promoted. Our study illustrates the necessity of guidelines, social, institutional and parents support for improving health-related behavior in cancer survivors, in order to improve their life beyond cancer. Further future research should clarify the effects of physical activity on HL management and etiology, to reach definitive conclusions and develop specific policy recommendations.

\section{Conflict of Interest Statement}

The authors declare no conflicts of interests.

\section{About the Authors}

Dario Colella, Full Professor of Methods of Didactics and Motor Activities, Department of Humanities, Cultural Heritage, Education Sciences, University of Foggia, Foggia, Italy. Domenico Monacis. PhD Student, Department of Humanities, Cultural Heritage, Education Sciences, University of Foggia, Foggia, Italy. 


\section{References}

Abarca-Gómez, L., Abdeen, Z. A., Hamid, Z. A., Abu-Rmeileh, N. M., Acosta-Cazares, B., Acuin, C., ... Ezzati, M. (2017). Worldwide trends in body-mass index, underweight, overweight, and obesity from 1975 to 2016: a pooled analysis of 2416 population-based measurement studies in $128 \& \# x b 7 ; 9$ million children, adolescents, and adults. The Lancet, 390(10113), 2627-2642. https://doi.org/10.1016/S0140-6736(17)32129-3

Abrignani, M. G., Lucà, F., Favilli, S., Benvenuto, M., Rao, C. M., Di Fusco, S. A., ... Gulizia, M. M. (2019). Lifestyles and Cardiovascular Prevention in Childhood and Adolescence. Pediatric Cardiology, 40(6), 1113-1125. https://doi.org/10.1007/s00246019-02152-w

Al-Khudairy, L., Loveman, E., Colquitt, J. L., Mead, E., Johnson, R. E., Fraser, H., ... Rees, K. (2017). Diet, physical activity and behavioural interventions for the treatment of overweight or obese adolescents aged 12 to 17 years. The Cochrane Database of Systematic Reviews, 6(6), CD012691. https://doi.org/10.1002/14651858.CD012691

Bhaskaran, K., Dos-Santos-Silva, I., Leon, D. A., Douglas, I. J., \& Smeeth, L. (2018). Association of BMI with overall and cause-specific mortality: a population-based cohort study of 3.6 million adults in the UK. The Lancet. Diabetes E Endocrinology, 6(12), 944-953. https://doi.org/10.1016/S2213-8587(18)30288-2

Bøhn, S. H., Lie, H. C., Reinertsen, K. V, Fosså, S. D., Haugnes, H. S., Kiserud, C. E., ... Thorsen, L. (2020). Lifestyle among long-term survivors of cancers in young adulthood. Support Care Cancer. https://doi.org/10.1007/s00520-020-05445-6

Bruijns, B. A., Adamo, K. B., Burke, S. M., Carson, V., Irwin, J. D., Naylor, P.-J., ... Tucker, P. (2019). Exploring the physical activity and screen-viewing-related knowledge, training, and self-efficacy of early childhood education candidates. BMC Pediatrics, 19(1), 5. https://doi.org/10.1186/s12887-018-1358-6

Brunet, J., Wurz, A., \& Shallwani, S. M. (2018). A scoping review of studies exploring physical activity among adolescents and young adults diagnosed with cancer. Psycho-oncology, 27(8), 1875-1888. https://doi.org/10.1002/pon.4743

Celind, J., Ohlsson, C., Bygdell, M., Martikainen, J., Lewerin, C., \& Kindblom, J. M. (2020). Childhood body mass index is associated with the risk of adult hematologic malignancies in men-The best Gothenburg cohort. International Journal of Cancer, 147(9), 2355-2362. https://doi.org/10.1002/ijc.33015

Crombie, J. L., \& LaCasce, A. S. (2019). Current considerations in AYA Hodgkin lymphoma. British Journal of Haematology, 184(1), 72-81. https://doi.org/10.1111/bjh.15640

Davies, G. A., Strader, C., Chibbar, R., Papatheodorou, S., \& Dmytriw, A. A. (2020). The relationship between physical activity and lymphoma: a systematic review and meta analysis. BMC Cancer, 20(1), 962. https://doi.org/10.1186/s12885-020-07431-x

Deisenroth, A., Söntgerath, R., Schuster, A. J., von Busch, C., Huber, G., Eckert, K., ... Wiskemann, J. (2016). Muscle strength and quality of life in patients with 
childhood cancer at early phase of primary treatment. Pediatric Hematology and Oncology, 33(6), 393-407. https://doi.org/10.1080/08880018.2016.1219796

Ford-Smith, C. D., Wyman, J. F., Elswick, R. K. J., Fernandez, T., \& Newton, R. A. (1995). Test-retest reliability of the sensory organization test in noninstitutionalized older adults. Archives of Physical Medicine and Rehabilitation, 76(1), 77-81. https://doi.org/10.1016/s0003-9993(95)80047-6

García-Hermoso, A., Ramírez-Vélez, R., Alfonso-Rosa, R. M., \& Del Pozo Cruz, B. (2020). Cardiorespiratory fitness, physical activity, sedentary behavior, and circulating white blood cells in US youth. Scandinavian Journal of Medicine $\mathcal{E}$ Science in Sports. https://doi.org/10.1111/sms.13845

Gonçalves, C. A. M., Dantas, P. M. S., Dos Santos, I. K., Dantas, M., da Silva, D. C. P., Cabral, B. G. de A. T., ... Júnior, G. B. C. (2019). Effect of Acute and Chronic Aerobic Exercise on Immunological Markers: A Systematic Review. Frontiers in Physiology. https://doi.org/10.3389/fphys.2019.01602

Hooke, M. C., Hoelscher, A., Tanner, L. R., Langevin, M., Bronas, U. G., Maciej, A., \& Mathiason, M. A. (2019). Kids Are Moving: A Physical Activity Program for Children with Cancer. Journal of Pediatric Oncology Nursing: Official Journal of the Association of Pediatric Oncology Nurses, 36(6), 379-389. https://doi.org/10.1177/1043454219858607

Hosker, D. K., Elkins, R. M., \& Potter, M. P. (2019). Promoting Mental Health and Wellness in Youth Through Physical Activity, Nutrition, and Sleep. Child and Adolescent Psychiatric Clinics of North America, 28(2), 171-193. https://doi.org/10.1016/j.chc.2018.11.010

Kowaluk, A., Woźniewski, M., \& Malicka, I. (2019). Physical Activity and Quality of Life of Healthy Children and Patients with Hematological Cancers. International Journal of Environmental Research and Public Health, 16(15). https://doi.org/10.3390/ijerph16152776

Kowaluk, A., Woźniewski, M., \& Malicka, I. (2019). Physical Activity and Quality of Life of Healthy Children and Patients with Hematological Cancers. International Journal of Environmental Research and Public Health, 16(15). https://doi.org/10.3390/ijerph16152776

Kuczmarski, R. J., Ogden, C. L., Guo, S. S., Grummer-Strawn, L. M., Flegal, K. M., Mei, Z., ... Johnson, C. L. (2002). 2000 CDC Growth Charts for the United States: methods and development. Vital and Health Statistics. Series 11, Data from the National Health Survey, (246), 1-190.

Matthews, C. E., Moore, S. C., Arem, H., Cook, M. B., Trabert, B., Hakansson, N., ... Lee, I. M. (2020). Amount and Intensity of Leisure-Time Physical Activity and Lower Cancer Risk. Journal of Clinical Oncology, 38(7), 686-697. https://doi.org/10.1200/jco.19.02407

Mauz-Körholz, C., Metzger, M. L., Kelly, K. M., Schwartz, C. L., Castellanos, M. E., Dieckmann, K., ... Körholz, D. (2015). Pediatric Hodgkin Lymphoma. Journal of 
Clinical Oncology : Official Journal of the American Society of Clinical Oncology, 33(27), 2975-2985. https://doi.org/10.1200//CO.2014.59.4853

Moher, D., Liberati, A., Tetzlaff, J., \& Altman, D. G. (2009). Preferred Reporting Items for Systematic Reviews and Meta-Analyses: The PRISMA Statement. PLoS Medicine, 6, e1000097. https://doi.org/10.1371/journal.pmed.1000097

Mounier, N., Anthony, S., Busson, R., Thieblemont, C., Ribrag, V., Tilly, H., ... HenryAmar, M. (2019). Long-term fatigue in survivors of non-Hodgkin lymphoma: The Lymphoma Study Association SIMONAL cross-sectional study. Cancer, 125(13), 2291-2299. https://doi.org/10.1002/cncr.32040

Munsie, C., Ebert, J., Joske, D., \& Ackland, T. (2019). The Benefit of Physical Activity in Adolescent and Young Adult Cancer Patients During and After Treatment: A Systematic Review. Journal of Adolescent and Young Adult Oncology, 8(5), 512-524. https://doi.org/10.1089/jayao.2019.0013

National Cancer Institute (n.d.). retrieved from https://www.cancer.gov/types/lymphoma/hp/child-hodgkin-treatment-pdq

Puente-Maestu, L., \& Stringer, W. W. (2018, February). Physical activity to improve health: do not forget that the lungs benefit too. The European Respiratory Journal. England. https://doi.org/10.1183/13993003.02468-2017

Reulen, R. C., Zeegers, M. P., Jenkinson, C., Lancashire, E. R., Winter, D. L., Jenney, M. E., \& Hawkins, M. M. (2006). The use of the SF-36 questionnaire in adult survivors of childhood cancer: evaluation of data quality, score reliability, and scaling assumptions. Health and Quality of Life Outcomes, 4, 77. https://doi.org/10.1186/1477-7525-4-77

Robison, L. L., Green, D. M., Hudson, M., Meadows, A. T., Mertens, A. C., Packer, R. J., ... Zeltzer, L. K. (2005). Long-term outcomes of adult survivors of childhood cancer. Cancer, 104(S11), 2557-2564. https://doi.org/10.1002/cncr.21249

Ross, W. L., Le, A., Zheng, D. J., Mitchell, H.-R., Rotatori, J., Li, F., ... Kadan-Lottick, N. S. (2018). Physical activity barriers, preferences, and beliefs in childhood cancer patients. Supportive Care in Cancer: Official Journal of the Multinational Association of Supportive Care in Cancer, 26(7), 2177-2184. https://doi.org/10.1007/s00520-017$\underline{4041-9}$

Saberi Hosnijeh, F., Kolijn, P. M., Casabonne, D., Nieters, A., Solans, M., Naudin, S., ... Vermeulen, R. (2020). Mediating effect of soluble B-cell activation immune markers on the association between anthropometric and lifestyle factors and lymphoma development. Scientific Reports, 10(1), 13814. https://doi.org/10.1038/s41598-020-70790-9

Singh, A. S., Saliasi, E., van den Berg, V., Uijtdewilligen, L., de Groot, R. H. M., Jolles, J., ... Chinapaw, M. J. M. (2019). Effects of physical activity interventions on cognitive and academic performance in children and adolescents: a novel combination of a systematic review and recommendations from an expert panel. British Journal of Sports Medicine, 53(10), 640-647. https://doi.org/10.1136/bjsports-2017-098136 
Sitlinger, A., Brander, D. M., \& Bartlett, D. B. (2020). Impact of exercise on the immune system and outcomes in hematologic malignancies. Blood Advances, 4(8), 18011811. https://doi.org/10.1182/bloodadvances.2019001317

Trachtenberg, E., Gurion, R., Mashiach, T., Tadmor, T., Kedmi, M., \& Dann, E. J. (2019). Recognizing severe fatigue and decline in quality of life in Hodgkin lymphoma survivors. Leukemia $\mathcal{E}$ Lymphoma, 60(14), 3449-3454. https://doi.org/10.1080/10428194.2019.1641803.

Troped PJ, Wiecha JL, Fragala MS, et al: Reliability and validity of YRBS physical activity items among middle school students. Med Sci Sports Exerc 39:416-425, 2007.

Van Dijk-Lokkart, E. M., Steur, L. M. H., Braam, K. I., Veening, M. A., Huisman, J., Takken, T., ... Van Litsenburg, R. R. L. (2019). Longitudinal development of cancer-related fatigue and physical activity in childhood cancer patients. Pediatric Blood E Cancer, 66(12), e27949. https://doi.org/10.1002/pbc.27949.

Wampler, M., Miaskowski, C., Byl, N., Rugo, H., \& Topp, K. (2006). The Modified Total Neuropathy Score: A Clinically Feasible and Valid Measure of Taxane-Induced Peripheral Neuropathy in Women with Breast Cancer.

Ware, J. E. J., \& Sherbourne, C. D. (1992). The MOS 36-item short-form health survey (SF36). I. Conceptual framework and item selection. Medical Care, 30(6), 473-483.

Wiseman, M. J. (2019, September). Nutrition and cancer: prevention and survival. The British Journal of Nutrition. England. https://doi.org/10.1017/S0007114518002222.

World Cancer Research Fund (2018) Diet, nutrition, physical activity and cancer: a global perspective. http://www.wcrf.org/dietandcancerreport (accessed August 2018).

Yu, J., Tao, Y., Dou, J., Ye, J., Yu, Y., \& Jin, L. (2018). The dose-response analysis between BMI and common chronic diseases in northeast China. Scientific Reports, 8(1), 4228. https://doi.org/10.1038/s41598-018-22551-y.

Zhang, T., Xu, J., Li, S., Bazzano, L. A., He, J., Whelton, P. K., \& Chen, W. (2019). Trajectories of childhood BMI and adult diabetes: the Bogalusa Heart Study. Diabetologia, 62(1), 70-77. https://doi.org/10.1007/s00125-018-4753-5. 
Dario Colella, Domenico Monacis

ASSESSING THE EFFECTS OF PHYSICAL ACTIVITY ON CHILDREN AND

ADOLESCENTS HODGKIN'S LYMPHOMA SURVIVORS: A SYSTEMATIC REVIEW

Creative Commons licensing terms

Authors will retain the copyright of their published articles agreeing that a Creative Commons Attribution 4.0 International License (CC BY 4.0) terms will be applied to their work. Under the terms of this license, no permission is required from the author(s) or publisher for members of the community to copy, distribute, transmit or adapt the article content, providing a proper, prominent and unambiguous attribution to the authors in a manner that makes clear that the materials are being reused under permission of a Creative Commons License. Views, opinions and conclusions expressed in this research article are views, opinions and conclusions of the author(s). Open Access Publishing Group and European Journal of Physical Education and Sport Science shall not be responsible or answerable for any loss, damage or liability caused in relation to/arising out of conflict of interests, copyright violations and inappropriate or inaccurate use of any kind content related or integrated on the research work. All the published works are meeting the Open Access Publishing requirements and can be freely accessed, shared, modified, distributed and used in educational, commercial and non-commercial purposes under a Creative Commons attribution 4.0 International License (CC BY 4.0). 